\title{
Genetics of Resistance to Wheat Leaf Rust, Stem Rust, and Powdery Mildew in Aegilops sharonensis
}

\author{
P. D. Olivera, E. Millet, Y. Anikster, and B. J. Steffenson
}

First and fourth authors: Department of Plant Pathology, University of Minnesota, St. Paul 55108; and second and third authors: Institute for Cereal Crops Improvement, Tel Aviv University, Ramat Aviv 69978, Israel.

Accepted for publication 13 November 2007.

\begin{abstract}
Olivera, P. D., Millet, E., Anikster, Y., and Steffenson, B. J. 2008. Genetics of resistance to wheat leaf rust, stem rust, and powdery mildew in Aegilops sharonensis. Phytopathology 98:353-358.

Aegilops sharonensis (Sharon goatgrass) is a wild relative of wheat and a rich source of genetic diversity for disease resistance. The objectives of this study were to determine the genetic basis of leaf rust, stem rust, and powdery mildew resistance in A. sharonensis and also the allelic relationships between genes controlling resistance to each disease. Progeny from crosses between resistant and susceptible accessions were evaluated for their disease reaction at the seedling and/or adult plant stage to determine the number and action of genes conferring resistance. Two different genes

sistance to stem rust race TPMK was conferred by two genes in accessions 1644 and 603. A contingency test revealed no association between genes conferring resistance to leaf rust race THBJ and stem rust race TTTT or between genes conferring resistance to stem rust race TTTT and powdery mildew isolate UM06-01, indicating that the respective resistance genes are not linked. Three accessions (1644, 2229, and 1193) were found to carry a single gene for resistance to powdery mildew. Allelism tests revealed that the resistance gene in accession 1644 is different from the respective single genes present in either 2229 or 1193 . The simple inheritance of leaf rust, stem rust, and powdery mildew resistance in A. sharonensis should simplify the transfer of resistance to wheat in wide crosses.
\end{abstract} conferring resistance to leaf rust races THBJ and BBBB were identified in accessions 1644 and 603 . For stem rust, the same single gene was found to confer resistance to race TTTT in accessions 1644 and 2229. Re-
Additional keywords: germplasm resources, wild wheat.
Aegilops sharonensis Eig (common name: Sharon goatgrass) is a wild relative of wheat, endemic to the coastal plain of Israel and southern Lebanon (28). The species belongs to the secondary gene pool of wheat and possesses the $\mathrm{S}^{1}$ genome, which is homeologous to the B genome of wheat (4). Increasing urbanization and agricultural development threaten many A. sharonensis populations across its native range (19); thus, renewed efforts to collect and characterize additional accessions have been initiated $(19,21)$. A. sharonensis is a rich source of genes for disease and insect resistance. Previous investigators have identified accessions with resistance to leaf rust (caused by Puccinia triticina Eriks.), stem rust (caused by $P$. graminis Pers.: Pers f. sp. tritici Eriks. \& E. Henn), stripe rust (caused by $P$. striiformis Westend. f. sp. tritici Eriks.), powdery mildew (caused by Blumeria graminis [DC] E.O. Speer. f. sp. tritici Em. Marchal), Karnal bunt (caused by Tilletia indica Mitra [Neovossia indica Mitra] Mundkur), tan spot (caused by Pyrenophora tritici-repentis [Died.] Drechs., anamorph Drechslera tritici-repentis [Died.] Shoem.), spot blotch (caused Cochliobolus sativus [Ito \& Kurib.] Drechs. ex Dastur, anamorph: Bipolaris sorokiniana [Sacc.] Shoem.) $(1,5,6,14,21,27$, 29), Hessian fly (caused by Mayetiola destructor [Say]), and greenbug (caused by Schizaphis graminum [Rondani]) (6). In spite of several genetic constraints for gene transfer from $A$. sharonensis into cultivated wheat (18), successful introgression of leaf rust and stripe rust resistance genes has been achieved (15). The potential for increasing the diversity of disease resistance in wheat with genes from A. sharonensis is great as Olivera et al.

Corresponding author: B. J. Steffenson; E-mail address: bsteffen@umn.edu

doi:10.1094/PHYTO-98-3-0353

(c) 2008 The American Phytopathological Society
(21) recently identified many accessions with resistance to the important wheat diseases of leaf rust, stem rust, stripe rust, powdery mildew, spot blotch, and tan spot.

The most effective and environmentally sound means of combating wheat diseases is through the use of host resistance. Novel resistance alleles carried in wild wheats are an important source of genetic diversity for countering virulence shifts in pathogen populations. To develop an efficient wide-crossing program using wheat relatives such as $A$. sharonensis, it is important to obtain information on the number and mode of action of genes controlling traits of interest. For some species, these genetic studies are best done within the wild species itself before any attempt at wide crossing is made. The objectives of this study were to determine the genetic basis of leaf rust, stem rust, and powdery mildew resistance in A. sharonensis and also the allelic relationships between genes controlling resistance to each disease. Leaf rust, stem rust, and powdery mildew were targeted in this study because they are important on wheat in many production areas $(9,11,22,24)$

\section{MATERIALS AND METHODS}

Plant materials. Four A. sharonensis accessions from Israel (Table 1) were selected for this study based on their differential reaction to wheat leaf rust, stem rust, and powdery mildew (21). Accession 2229 was collected from En HaMifraz in the Northern Coastal (Akko) Plain, 1193 from Hefzi Bah in the Central Coastal Plain, 603 from Palmahim in the Southern Coastal Plain, and 1644 from Ashdod in the Southern Coastal Plain. In total, seven crosses were developed to investigate the number of genes controlling resistance or to determine the relationship between resistance genes in allelism tests. $F_{1}$ plants were grown and selfed to produce $F_{2}$ populations. One to three different seed lots from 
each $\mathrm{F}_{2}$ population were used for the disease evaluations (Table 2 ). Individual $F_{2}$ plants were then selfed to produce $F_{2: 3}$ families. Each $\mathrm{F}_{2}$ seed lot was evaluated for reaction to a single pathogen, with the exception of seed lot number 1-A from 1644/1193 and lot number 2-A from 1193/1644. Seed lot number 1-A from $1644 / 1193$ was evaluated to leaf rust race THBJ and then stem rust race TTTT at the seedling stage in sequential inoculations conducted 14 days apart, whereas seed lot number 2-A from the reciprocal cross $1193 / 1644$ was evaluated to stem rust race TTTT and then leaf rust race THBJ in sequential inoculations of the same interval. At the adult plant stage, these same $\mathrm{F}_{2}$ plants were inoculated with leaf rust race THBJ (on the flag and flag-1 leaves) and stem rust race TTTT (on the upper two internodes) on the same day. Care was taken to not overspray the respective pathogens onto the other plant tissues. All the spikes of $F_{1}$ and $F_{2}$ plants were bagged before anthesis to prevent any chance of crosspollination.

Pathogen isolates. The pathogen races/isolates used in this study were selected based on their differential virulence pattern and/or importance in agriculture (21). Race THBJ of $P$. triticina has a wide spectrum of virulence and is a common race in the Great Plains (13). Race BBBB possesses the narrowest virulence spectrum of any leaf rust pathogen culture in the USDA-ARS Cereal Disease Laboratory collection. It was selected because it may have the potential to detect the presence of additional resistance genes in the A. sharonensis accessions. Both races were purified by single uredinium isolation, verified for their virulence phenotype, and then increased on seedlings of the susceptible wheat cultivar Thatcher (Cltr 10003). Race TTTT of $P$. graminis f. sp. tritici is the most widely virulent race known in the United States and produces high infection types (IT) on all of the wheat stem rust differential lines (23). Race TPMK was the predominant stem rust race in all regions of the United States during the 1990s (17). Because this race possesses a narrower virulence spectrum than race TTTT, it may detect the presence of additional stem rust resistance genes in A. sharonensis. Both races were purified by single uredinium isolation, verified for their virulence phenotype, and then increased on the susceptible wheat cultivar McNair 701 (Cltr 15288). Isolate UM06-01 of B. graminis f. sp. tritici was derived from a single pustule collected in the greenhouse at the University of Minnesota St. Paul campus. The isolate was characterized for its virulence phenotype (8) and then increased on the wheat cv. Thatcher (Cltr 10003).

Plant growth conditions, inoculation protocols, and disease assessment. The sowing, maintenance, inoculation, and disease assessment protocols for plant materials were done as described by Olivera et al. (21). A summary of the disease evaluations of $A$. sharonensis crosses and seed lots including pathogen races used,

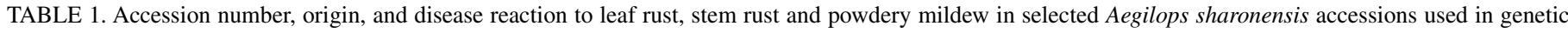
studies conducted in the greenhouse at St. Paul, MN, in 2004 and 2006

\begin{tabular}{|c|c|c|c|c|c|c|}
\hline \multirow[b]{3}{*}{ Accession number } & \multirow[b]{3}{*}{ Origin } & \multicolumn{5}{|c|}{ Disease reaction } \\
\hline & & \multicolumn{2}{|c|}{ Leaf rust pathogen races } & \multicolumn{2}{|c|}{ Stem rust pathogen races } & \multirow{2}{*}{$\frac{\text { Powdery mildew pathogen isolate }}{\text { UM06-01 }}$} \\
\hline & & THBJ & $\mathrm{BBBB}$ & TTTT & TPMK & \\
\hline 2229 & En HaMifraz & $33-^{\mathrm{a}}$ & $3+4$ & $1-1$ & $0 ; 1$ & $0 ;-$ \\
\hline 1193 & Hefzi Bah & 3 & $3+$ & 3 & $33-$ & $1-1$ \\
\hline 603 & Palmahim & 1 & 0 & 3 & 1 & $33+$ \\
\hline 1644 & Ashdod & $0 ; 1-$ & 0 & 10 & $0 ; 1-$ & $0 ;-$ \\
\hline
\end{tabular}

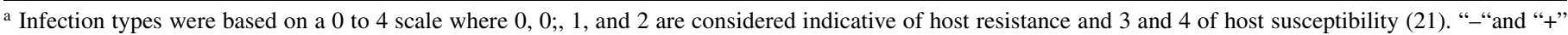
indicate lower (-) or higher (+) sporulation for infection types than described in the original scale.

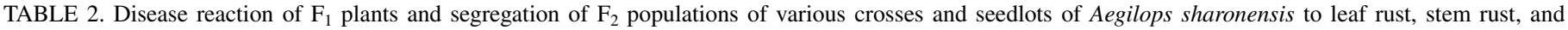
powdery mildew conducted in the greenhouse at St. Paul, MN, in 2006 and 2007

\begin{tabular}{|c|c|c|c|c|c|c|c|c|c|c|c|}
\hline \multirow[b]{2}{*}{ Cross $^{\mathrm{a}}$} & \multirow[b]{2}{*}{ Seed lot no. ${ }^{b}$} & \multirow[b]{2}{*}{ Pathogen } & \multirow[b]{2}{*}{ Race/isolate } & \multirow[b]{2}{*}{$\begin{array}{c}\text { Growth } \\
\text { stage }\end{array}$} & \multicolumn{2}{|c|}{$\mathrm{F}_{1}$} & \multicolumn{5}{|c|}{$\mathrm{F}_{2}$} \\
\hline & & & & & $\begin{array}{l}\text { No. plants } \\
\text { tested }\end{array}$ & $\mathrm{IT}^{\mathrm{c}}$ & Resistant & Susceptible & $\begin{array}{l}\text { Ratio } \\
\text { tested }\end{array}$ & $\chi^{2}$ & $P$ value \\
\hline $1644(\mathrm{R}) / 1193(\mathrm{~S})$ & $1-\mathrm{A}$ & LR & THBJ & Seedling & 3 & $1-0$ & 88 & 33 & $3: 1$ & 0.33 & 0.56 \\
\hline $1644(\mathrm{R}) / 1193(\mathrm{~S})$ & $1-\mathrm{A}$ & LR & THBJ & Adult & 3 & $1-1$ & 92 & 20 & $3: 1$ & 3.05 & 0.08 \\
\hline $1193(\mathrm{~S}) / 1644(\mathrm{R})$ & $2-\mathrm{A}$ & LR & THBJ & Seedling & 4 & $10 ; 1+$ & 100 & 29 & $3: 1$ & 0.44 & 0.51 \\
\hline $1193(\mathrm{~S}) / 1644(\mathrm{R})$ & $2-\mathrm{A}$ & LR & THBJ & Adult & 4 & 10 & 105 & 27 & $3: 1$ & 1.46 & 0.23 \\
\hline $603(\mathrm{R}) / 1193(\mathrm{~S})$ & $4-\mathrm{A}$ & LR & THBJ & Seedling & 2 & $1-0$ & 117 & 28 & $3: 1$ & 2.50 & 0.11 \\
\hline $603(\mathrm{R}) / 1193(\mathrm{~S})$ & $4-\mathrm{A}$ & LR & THBJ & Adult & 2 & $0 ; 1-$ & 102 & 26 & $3: 1$ & 1.50 & 0.22 \\
\hline $1644(\mathrm{R}) / 603(\mathrm{R})$ & $3-A$ & LR & THBJ & Seedling & 1 & $0 ; 1-$ & 273 & 24 & $15: 1$ & 1.67 & 0.19 \\
\hline $1644(\mathrm{R}) / 1193(\mathrm{~S})$ & $1-\mathrm{A}$ & SR & TTTT & Seedling & 3 & $1-10$ & 84 & 42 & $3: 1$ & 4.67 & 0.03 \\
\hline $1644(\mathrm{R}) / 1193(\mathrm{~S})$ & $1-\mathrm{A}$ & SR & TTTT & Adult & 3 & $11-$ & 90 & 23 & $3: 1$ & 1.30 & 0.25 \\
\hline $1193(\mathrm{~S}) / 1644(\mathrm{R})$ & $2-\mathrm{A}$ & SR & TTTT & Seedling & 4 & $11-1+$ & 94 & 39 & $3: 1$ & 1.33 & 0.25 \\
\hline $1193(\mathrm{~S}) / 1644(\mathrm{R})$ & $2-\mathrm{A}$ & SR & TTTT & Adult & 4 & 1 & 90 & 42 & $3: 1$ & 3.27 & 0.07 \\
\hline $1193(\mathrm{~S}) / 2229$ (R) & $6-A$ & SR & TTTT & Seedling & 1 & 1 & 112 & 30 & $3: 1$ & 1.14 & 0.29 \\
\hline $1644(\mathrm{R}) / 2229(\mathrm{R})$ & $5-\mathrm{A}$ & SR & TTTT & Seedling & 2 & $1-0$ & 160 & 0 & $15: 1$ & 10.67 & 0.001 \\
\hline $1644(\mathrm{R}) / 1193(\mathrm{~S})$ & $1-B$ & SR & TPMK & Seedling & 一 & - & 114 & 11 & $15: 1$ & 1.39 & 0.24 \\
\hline $603(\mathrm{R}) / 1193(\mathrm{~S})$ & $4-B$ & SR & TPMK & Seedling & - & - & 143 & 13 & $15: 1$ & 1.16 & 0.28 \\
\hline $1644(\mathrm{R}) / 2229(\mathrm{R})$ & $5-B$ & SR & TPMK & Seedling & - & - & 258 & 0 & $15: 1$ & 17.20 & $3.36 \mathrm{E}^{-5}$ \\
\hline $1644(\mathrm{R}) / 603(\mathrm{~S})$ & $3-B$ & PM & UM06-01 & Seedling & 1 & 0 & 99 & 38 & $3: 1$ & 0.55 & 0.46 \\
\hline $603(\mathrm{~S}) / 1193(\mathrm{R})$ & $4-\mathrm{C}$ & PM & UM06-01 & Seedling & 2 & $1-0$ & 127 & 40 & $3: 1$ & 0.10 & 0.75 \\
\hline $2229(\mathrm{R}) / 603(\mathrm{~S})$ & $7-A$ & PM & UM06-01 & Seedling & 1 & $0 ; 1-$ & 99 & 40 & $3: 1$ & 0.26 & 0.30 \\
\hline $1644(\mathrm{R}) / 1193(\mathrm{R})$ & $1-\mathrm{C}$ & PM & UM06-01 & Seedling & 2 & $1-0$ & 284 & 25 & $15: 1$ & 1.79 & 0.18 \\
\hline $1644(\mathrm{R}) / 2229(\mathrm{R})$ & $5-\mathrm{C}$ & PM & UM06-01 & Seedling & 1 & 0 & 150 & 8 & $15: 1$ & 0.38 & 0.54 \\
\hline
\end{tabular}

${ }^{a}$ Female parent/male parent; $(\mathrm{R})$ and $(\mathrm{S})$ indicate the resistant and susceptible parent, respectively.

b Seed lot refers to a subsample derived from the same $\mathrm{F}_{2}$ population.

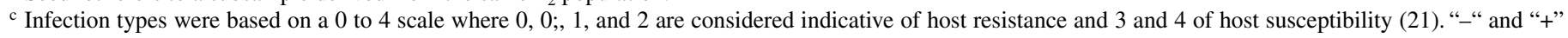
indicate lower (-) or higher (+) sporulation for infection types than described in the original scale. 
plant growth stage, and filial generation, is given in Tables 2 and 3 . $F_{2}$ seedlings from the populations $1644 / 1193$ and $1193 / 1644$ were inoculated at the three to four leaf stage instead of the two leaf stage with stem rust race TTTT and leaf rust race THBJ, respectively. When $\mathrm{F}_{2: 3}$ families were evaluated against different pathogens or races, independent evaluations were made using different subsamples of the same $\mathrm{F}_{2: 3}$ family. For the summary of data, plants exhibiting IT from zero to two were classified as resistant, whereas those exhibiting IT from three to four were classified as susceptible $(12,23)$.

Inheritance and allelism studies. To determine the genetic control of resistance to the three diseases, crosses between resistant and susceptible A. sharonensis accessions (Tables 1 and 2) were evaluated. $F_{1}$ plants were evaluated to assess gene action. $F_{2}$ populations (120 to 170 plants) and $F_{2: 3}$ families were then evaluated to determine the inheritance of resistance based on phenotypic ratios. Twenty plants from each $\mathrm{F}_{2: 3}$ family were screened in these tests. According to Hanson (7), this $F_{2: 3}$ family size has a $99 \%$ probability of distinguishing between segregating and nonsegregating families for monogenic inheritance. The allelism tests involved testing $\mathrm{F}_{2}$ populations (160 to 320 plants) derived from crosses between two A. sharonensis accessions resistant to the respective diseases of leaf rust, stem rust, and powdery mildew (Tables 1 and 2).

Data analysis. The chi-square $\left(\chi^{2}\right)$ test was applied to determine the goodness of fit for expected genetic ratios in the $\mathrm{F}_{2}$ and $\mathrm{F}_{2: 3}$ generations. Additionally, chi-square values also were calculated from a contingency table to assess the relationship of the reactions of $A$. sharonensis to different fungal pathogens (e.g., $P$. triticina versus $P$. graminis $\mathrm{f}$. $\mathrm{sp}$. tritici), races within a pathogen (e.g., P. triticina races BBBB versus THBJ), or growth stages (e.g., seedling versus adult plant).

\section{RESULTS AND DISCUSSION}

Inheritance of leaf rust resistance. $F_{1}$ plants from all the evaluated crosses between resistant and susceptible accessions exhibited IT (range of 0 ; to $1+$; Table 2) that were similar to the resistant parent (Table 1) to race THBJ of $P$. triticina at the seedling and adult plant stage. Moreover, all of the $F_{2}$ populations from crosses between resistant and susceptible accessions segregated in their response to leaf rust. The number of resistant/ susceptible plants conformed to a 3:1 ratio at both the seedling and adult plant stages (Table 2). This indicates that resistance to race THBJ in accessions 1644 and 603 is controlled by a single dominant gene. In the $\mathrm{F}_{2: 3}$ generation, the populations segregated in a 1:2:1 ratio for homozygous resistant/segregating/homozygous susceptible families, confirming that a single dominant gene is involved in conferring resistance to race THBJ (Table 3).

The chi-square value from the contingency table indicated a strong association in the reaction to race THBJ at the seedling and adult plant stages (Table 4), suggesting that the same gene conditions resistance at both growth stages. This result is in contrast to the work of Snyman et al. (26) who documented adult plant leaf rust resistance in A. sharonensis accessions that were susceptible at the seedling stage. Moreover, Lr35, a gene transferred from the close relative $A$. speltoides (10), also confers adult plant resistance to leaf rust. In this study, we selected accessions that exhibited a resistant reaction at both seedling and adult plant stages (21); thus, we cannot discount the possibility that some A. sharonensis accessions may possess adult plant resistance only.

In the allelism test, the $\mathrm{F}_{2}$ population derived from the cross between the two resistant accessions (1644 and 603 from the nearby sites of Ashdod and Palmahim, respectively) segregated in an approximate 15:1 ratio for resistant and susceptible plants to

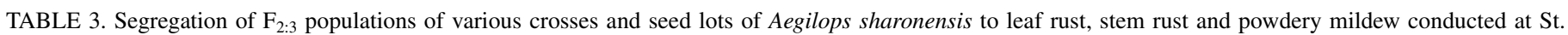
Paul, MN, in 2006 and 2007

\begin{tabular}{|c|c|c|c|c|c|c|c|c|c|}
\hline \multirow[b]{2}{*}{$\operatorname{Cross}^{\mathrm{a}}$} & \multirow[b]{2}{*}{ Seed lot no. ${ }^{b}$} & \multirow[b]{2}{*}{ Pathogen } & \multirow[b]{2}{*}{ Race/isolate } & \multicolumn{3}{|c|}{$\mathrm{F}_{2: 3}$ families } & \multirow[b]{2}{*}{ Ratio tested } & \multirow[b]{2}{*}{$\chi^{2}$} & \multirow[b]{2}{*}{$P$ value } \\
\hline & & & & Resistant & Segregating & Susceptible & & & \\
\hline $1644(\mathrm{R}) / 1193(\mathrm{~S})$ & $1-\mathrm{A}$ & LR & THBJ & 33 & 54 & 34 & $1: 2: 1$ & 1.41 & 0.49 \\
\hline $1193(\mathrm{~S}) / 1644(\mathrm{R})$ & $2-\mathrm{A}$ & LR & THBJ & 29 & 65 & 39 & $1: 2: 1$ & 1.57 & 0.46 \\
\hline $603(\mathrm{R}) / 1193(\mathrm{~S})$ & $4-\mathrm{A}$ & LR & THBJ & 28 & 62 & 35 & $1: 2: 1$ & 0.79 & 0.67 \\
\hline $1644(\mathrm{R}) / 1193(\mathrm{~S})$ & $1-\mathrm{A}$ & LR & $\mathrm{BBBB}$ & 30 & 58 & 34 & $1: 2: 1$ & 0.56 & 0.76 \\
\hline $603(\mathrm{R}) / 1193(\mathrm{~S})$ & $4-\mathrm{A}$ & LR & BBBB & 29 & 67 & 32 & $1: 2: 1$ & 0.42 & 0.81 \\
\hline $1644(\mathrm{R}) / 1193(\mathrm{~S})$ & $1-\mathrm{A}$ & SR & TTTT & 32 & 56 & 34 & $1: 2: 1$ & 0.89 & 0.64 \\
\hline $1193(\mathrm{~S}) / 1644(\mathrm{R})$ & $2-\mathrm{A}$ & SR & TTTT & 41 & 60 & 34 & $1: 2: 1$ & 2.39 & 0.30 \\
\hline $1644(\mathrm{R}) / 603(\mathrm{~S})$ & $3-B$ & SR & TTTT & 29 & 66 & 25 & $1: 2: 1$ & 1.47 & 0.48 \\
\hline $1644(\mathrm{R}) / 603(\mathrm{~S})$ & $3-B$ & PM & UM06-01 & 31 & 35 & 55 & $1: 2: 1$ & 1.26 & 0.53 \\
\hline $603(\mathrm{~S}) / 1193(\mathrm{R})$ & 4-C & PM & UM06-01 & 46 & 68 & 38 & $1: 2: 1$ & 2.53 & 0.28 \\
\hline $2229(\mathrm{R}) / 603(\mathrm{~S})$ & $7-A$ & PM & UM06-01 & 33 & 74 & 28 & $1: 2: 1$ & 1.62 & 0.44 \\
\hline
\end{tabular}

${ }^{a}$ Female parent/male parent; (R) and (S) indicate the resistant and susceptible parent, respectively.

b Seed lot refers to a subsample derived from the same $\mathrm{F}_{2}$ population.

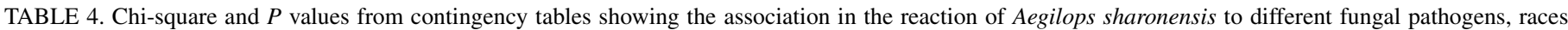
within a pathogen, or growth stages

\begin{tabular}{|c|c|c|c|c|c|}
\hline Fungal pathogen and races & Cross $^{\mathrm{a}}$ & Seed lot & Generation & $\chi^{2}$ & $P$ value \\
\hline$P$. triticina race $\mathrm{THBJ}^{\mathrm{b}}$ vs. $P$. graminis $\mathrm{f}$. sp. tritici race $\mathrm{TTTT}^{\mathrm{b}}$ & $1644 / 1193$ & $1-\mathrm{A}$ & $\mathrm{F}_{2: 3}$ & 2.37 & 0.67 \\
\hline P. triticina race $\mathrm{THBJ}^{\mathrm{b}}$ vs. $P$. graminis $\mathrm{f}$. sp. tritici race $\mathrm{TTTT}^{\mathrm{b}}$ & $1193 / 1644$ & $2-\mathrm{A}$ & $\mathrm{F}_{2: 3}$ & 2.22 & 0.69 \\
\hline P. graminis $\mathrm{f}$. sp. tritici race TTTT $^{\mathrm{b}}$ vs. B. graminis $\mathrm{f}$. sp. tritici isol. UM06-01 ${ }^{\mathrm{b}}$ & $1644 / 603$ & $3-\mathrm{B}$ & $\mathrm{F}_{2: 3}$ & 1.79 & 0.77 \\
\hline$P$. triticina race $\mathrm{THBJ}^{\mathrm{b}}$ vs. $P$. triticina race $\mathrm{BBBB}^{\mathrm{b}}$ & $1644 / 1193$ & $1-\mathrm{A}$ & $\mathrm{F}_{2: 3}$ & 160.8 & $9.75 \mathrm{E}^{-34}$ \\
\hline P. triticina race $\mathrm{THBJ}^{\mathrm{b}}$ vs. $P$. triticina race $\mathrm{BBBB}^{\mathrm{b}}$ & $603 / 1193$ & 4-A & $\mathrm{F}_{2: 3}$ & 170.7 & $7.23 \mathrm{E}^{-36}$ \\
\hline$P$. triticina race $\mathrm{THBJ}^{\mathrm{c}}$ vs. $P$. triticina race $\mathrm{THBJ}^{\mathrm{b}}$ & $1644 / 1193$ & $1-\mathrm{A}$ & $\mathrm{F}_{2}$ & 69.9 & $7.32 \mathrm{E}^{-17}$ \\
\hline$P$. triticina race $\mathrm{THBJ}^{\mathrm{c}}$ vs. $P$. triticina race $\mathrm{THBJ}^{\mathrm{b}}$ & $1193 / 1644$ & $2-\mathrm{A}$ & $\mathrm{F}_{2}$ & 105.3 & $1.04 \mathrm{E}^{-21}$ \\
\hline$P$. triticina race $\mathrm{THBJ}^{\mathrm{c}}$ vs. $P$. triticina race $\mathrm{THBJ}^{\mathrm{b}}$ & $603 / 1193$ & $4-\mathrm{A}$ & $\mathrm{F}_{2}$ & 54.8 & $1.31 \mathrm{E}^{-13}$ \\
\hline P. graminis $\mathrm{f}$. sp. tritici race $\mathrm{TTTT}^{\mathrm{c}}$ vs. $P$. graminis $\mathrm{f}$. sp. tritici race TTTT $^{\mathrm{b}}$ & $1644 / 1193$ & $1-\mathrm{A}$ & $\mathrm{F}_{2}$ & 47.8 & $4.85 \mathrm{E}^{-12}$ \\
\hline P. graminis $\mathrm{f}$. sp. tritici race $\mathrm{TTTT}^{\mathrm{c}}$ vs. $P$. graminis $\mathrm{f}$. sp. tritici race $\mathrm{TTTT}^{\mathrm{b}}$ & $1193 / 1644$ & $1-\mathrm{A}$ & $\mathrm{F}_{2}$ & 90.1 & $2.54 \mathrm{E}^{-21}$ \\
\hline
\end{tabular}

${ }^{a}$ Female parent/male parent.

b Seedling evaluation.

c Adult plant evaluation. 
race THBJ (Table 2). This indicates that the accessions carry different independently segregating dominant resistance genes. The diversity for leaf rust resistance genes found between accessions from different collection sites is not surprising given that Olivera et al. (21) found a high degree of variation in the frequency of resistant accessions between populations located in close proximity to each other, including the locations of Ashdod and Palmahim.

To identify additional leaf rust resistance genes in A. sharonensis, we evaluated $F_{2: 3}$ families from the crosses 1644/1193 and $603 / 1193$ for their reaction to race BBBB of P. triticina. Both crosses segregated in a 1:2:1 ratio for homozygous resistant/ segregating/homozygous susceptible families, indicating that a single dominant gene confers resistance to race BBBB (Table 3). The general reaction of the $F_{2: 3}$ families to race $\mathrm{BBBB}$ was the same as that found for race THBJ in nearly every case. Moreover, the chi-square value from the contingency table for $\mathrm{F}_{2: 3}$ families confirmed a strong association between the reactions to races THBJ and BBBB (Table 4). This suggests that accessions 1644 and 603 each carry a single dominant unique resistance gene that is effective against both pathogen races. Olivera et al. (21) found a high correspondence in the reactions of 107 accessions from Israel and Lebanon to P. triticina races THBJ, BBBB, and PNMQ, suggesting that the same dominant resistance gene might be acting in A. sharonensis. Our results agree with these findings as accessions 1644 and 603 were resistant not only to races THBJ and BBBB, but also race PNMQ (21). Races THBJ and PNMQ together possess virulence for 13 out of the $16 \mathrm{Lr}$ genes included in the leaf rust differential set (12), including $\operatorname{Lr} 9$ (from $A$. umbellulata) and Lr24 (from T. ponticum) (4). Thus, these selected A. sharonensis accessions are potentially valuable sources of novel $L r$ genes for wheat improvement. The single leaf rust resistance gene introgressed into wheat from A. sharonensis by Marais et al. (16) also was effective to a wide range of $P$. triticina races.

Inheritance of stem rust resistance. $F_{1}$ seedling and adult plants from all of the crosses between resistant and susceptible accessions exhibited IT (range of 0 ; to 1+; Table 2) that were similar to the resistant parent (Table 1) to race TTTT of $P$. graminis f. sp. tritici, indicating that resistance is controlled by a completely dominant gene(s). All but one (seed lot no. 1-A from $1644 / 1193$ with $P=0.03$ ) of the $\mathrm{F}_{2}$ populations segregated in an approximate $3: 1$ ratio (at $P>0.05$ ) for the number of resistant/ susceptible plants (Table 2). This indicates that resistance to race TTTT in accessions 1644 and 2229 is controlled by a single dominant gene. The deviation from the expected ratio in seed lot number 1-A from cross 1644/1193 could be due to the sequential inoculation, in which the initial leaf rust infection may have interfered with the subsequent stem rust infection (i.e., induced resistance) or possibly the misclassification of plants. However, at the adult plant stage, the segregation ratio in response to stem rust in this seed lot fit a 3:1 ratio (Table 2), confirming single gene control to this pathogen. All of the $\mathrm{F}_{2: 3}$ populations segregated in an approximate 1:2:1 ratio for homozygous resistant/segregating/ homozygous susceptible families, confirming the results found in the $\mathrm{F}_{2}$ generation (Table 3).

The chi-square value from the contingency table showed a strong association between the seedling reaction and adult plant reaction to race TTTT (Table 4). This indicates that the same gene conditions resistance at both growth stages, and that no additional genes are effective at the adult plant stage.

$F_{2}$ plants from crosses $1644 / 1193$ and $603 / 1193$ were evaluated for their reaction to race TPMK of $P$. graminis f. sp. tritici with the objective of identifying additional stem rust resistance genes in A. sharonensis. The $\mathrm{F}_{2}$ populations of both crosses segregated in an approximate 15:1 ratio for resistant and susceptible plants, indicating the presence of two independently segregating dominant genes conferring resistance to race TPMK (Table 2). Acces- sion 1644 carries at least two different stem rust resistance genes, one effective against races TTTT and TPMK, and the second only to race TPMK. In accession 603, two resistance genes effective against race TPMK also were identified, but neither of them was effective against race TTTT (Table 1). This work highlights the importance of using multiple races with different virulence spectra to identify different resistance genes in A. sharonensis. The identification of multiple stem rust resistance genes in $A$. sharonensis is in agreement with Gerechter-Amitai and Loegering (5), who postulated 12 or 15 different genes for resistance in 44 selected accessions of $A$. sharonensis and A. longissima using 20 cultures of $P$. graminis $\mathrm{f}$. sp. tritici. The presence of different stem rust resistance genes in $A$. sharonensis also was suggested by Olivera et al. (21), who reported a high level of variation in the frequency of resistance in $107 \mathrm{~A}$. sharonensis accessions to four different stem rust races and the absence of significant associations in the reactions elicited by them. The existence of a number of stem rust resistance genes appears to be a common feature of Aegilops species belonging to the section Sitopsis as two have been identified in A. speltoides (e.g., Sr32 and Sr39) and transferred into cultivated wheat (4).

In the allelism test, the $\mathrm{F}_{2}$ population derived from the cross between two resistant accessions (1644 and 2229) produced only resistant progeny to race TTTT (Table 2). This suggests that both accessions carry resistance alleles at the same locus or different genes that are tightly linked with each other. As observed in the allelism test with race TTTT, the $\mathrm{F}_{2}$ population derived from the cross between resistant accessions 1644 and 2229 produced only resistant progeny to race TPMK (Table 2), confirming the presence of the same or tightly linked resistance genes in the accessions.

Overall, these experiments suggest a more complex genetic system for stem rust resistance than leaf rust resistance in $A$. sharonensis. This is based on the fact that we identified accessions that carry multiple and different stem rust resistance genes.

Inheritance of powdery mildew resistance. $F_{1}$ plants from crosses between resistant and susceptible accessions exhibited IT (range of 0; to 1-; Table 2) similar to those of the resistant parent (Table 1) to isolate UM06-01 of B. graminis f. sp. tritici, indicating that resistance is controlled by a completely dominant gene(s) (Table 2). The derived $F_{2}$ populations all segregated in an approximate 3:1 ratio for resistant and susceptible plants (Table 2 ), indicating that resistance is controlled by a single dominant gene in accessions 1644,1193 , and 2229 . All of the $F_{2: 3}$ populations segregated in an approximate 1:2:1 ratio for homozygous resistant/segregating/homozygous susceptible families, corroborating the results found in the $\mathrm{F}_{2}$ generation (Table 3 ).

In the allelism tests, the $F_{2}$ populations made between the pairs of resistant accessions (i.e., 1644/2229 and 1644/1193) segregated for resistance and susceptibility to isolate UM06-01. In both crosses, the number of resistant/susceptible plants conformed to a 15:1 ratio as given by the chi-square test (Table 2). This result indicates that the resistance gene in accession 1644 (southern Coastal Plain) is different from the respective single genes present in either 2229 (northern Coastal Plain) or 1193 (central Coastal Plain). The relationship between the single genes present in accessions 2229 and 1193 cannot be resolved until the proper allelism test is made. From the evaluation of 107 A. sharonensis accessions for reaction to two isolates of $B$. graminis f. sp. tritici with different virulence spectra, Olivera et al. (21) postulated the presence of different resistance genes effective to each of the isolates tested. This result indicates that additional powdery mildew resistance genes may be identified in A. sharonensis using isolates with different virulence spectra. Multiple powdery mildew resistance genes have been identified in A. speltoides (Pm12, Pm29, and Pm32) (8) and A. tauschii (Pm2, Pm34) (8,20), indicating that the presence of multiple resistance genes to powdery mildew is a common feature in Aegilops species. 
Maternal effects. Reciprocal crosses were made to assess whether any maternal effects were involved in resistance. The reaction of $F_{1}$ plants and the segregation of $F_{2}$ and $F_{2: 3}$ populations from the reciprocal crosses of 1644/1193 and 1193/1644 indicated that no maternal effects were involved in the inheritance of leaf rust and stem rust resistance (Tables 2 and 3). A similar result was reported by Ecker et al. (2,3) in their study on the genetics of Septoria glume blotch resistance in the closely related species of $A$. speltoides and $A$. longissima. In contrast, marked differences were detected in the $\mathrm{F}_{2}$ segregation ratio of reciprocal crosses between leaf rust resistant and susceptible A. speltoides accessions (E. Millet, unpublished data). These contrasting results suggest that the influence of maternal factors in A. sharonensis may depend on the interaction of both the host and pathogen evaluated.

Relationship between genes controlling resistance to different pathogens. A. sharonensis, like other wild relatives, is a potential source of novel genes for disease resistance in wheat. Since gene introgression from A. sharonensis is a long and laborious process, it would be more efficient to utilize an accession that carries multiple and linked resistance genes so that more than one of them could be transferred to wheat. One of our objectives was to identify possible associations between genes for resistance to the three diseases. $F_{2: 3}$ families from the same seed lot of the reciprocal crosses 1644/1193 (no. 1-A) and 1193/1644 (no. 2-A), and from the cross $1644 / 603$ (no. 3-C) were evaluated for their reaction to race THBJ of $P$. triticina and race TTTT of $P$. graminis f. sp. tritici, and to isolate UM06-01 of B. graminis f. sp. tritici and race TTTT of $P$. graminis f. sp. tritici, respectively, to study the possible association between genes conferring resistance to the respective pathogens. For the reciprocal crosses 1644/1193 and $1193 / 1644$, the chi-square value from the contingency table revealed that the response to leaf rust is independent of the response to stem rust (Table 4). A lack of association also was observed in the response to powdery mildew and stem rust in the cross $1644 / 603$ (Table 4). The lack of association revealed by the contingency test indicates that different genes confer resistance to the respective pathogens and that the respective resistance genes are located at unlinked chromosomal positions. The presence of independently segregating leaf rust and stem rust resistance genes in A. sharonensis also was reported by Marais et al. (15). The lack of association between leaf rust and stem rust resistance genes will make the simultaneous introgression of resistance to both pathogens into hexaploid wheat a more difficult task.

This study was the first to characterize the genetics of disease resistance in A. sharonensis, and one of the few completed in any of the species of the section Sitopsis $(2,3)$. Our results clearly demonstrated that resistance to wheat leaf rust, stem rust, and powdery mildew in A. sharonensis is controlled by dominant genes with major effect. Similar findings were reported in several closely related Aegilops species of section Sitopsis to these same wheat pathogens. In fact, a number of these major resistance genes have been successfully introgressed into wheat; $\operatorname{Lr} 28, \operatorname{Lr} 35$, Lr36, Lr47, Lr51, Sr32, Sr39, Pm12, Pm29, and Pm32 from A. speltoides and Pm13 from A. longissima $(4,8,10,25)$. Prior knowledge regarding the inheritance of resistance in wild wheat relatives is important in selecting a transfer approach in alien gene introgression programs. The simple inheritance found in $A$. sharonensis indicates that the introgression of resistance genes to leaf rust, stem rust, and powdery mildew into wheat will be relatively straightforward, not withstanding the inherent genetic constraints of the wide cross (19).

\section{ACKNOWLEDGMENTS}

This research was funded in part by the Lieberman-Okinow Endowment at the University of Minnesota. We thank J. Kolmer and Y. Jin for providing rust cultures.

\section{LITERATURE CITED}

1. Anikster, Y., Manisterski, J., Long, D. L., and Leonard, K. J. 2005. Resistance to leaf rust, stripe rust, and stem rust in Aegilops spp. in Israel. Plant Dis. 89:303-308.

2. Ecker, R., Cahaner, A., and Dinoor, A. 1990. The inheritance of resistance to Septoria glume blotch. II. The wild wheat species Aegilops speltoides. Plant Breed. 104:218-223.

3. Ecker, R., Cahaner, A., and Dinoor, A. 1990. The inheritance of resistance to Septoria glume blotch. III. The wild wheat species Aegilops longissima. Plant Breed. 104:224-230.

4. Friebe, B., Jiang, J., Raupp, W. J., McIntosh, R. A., and Gill, B. S. 1996. Characterization of wheat-alien translocations conferring resistance to diseases and pests: Current status. Euphytica 91:59-87.

5. Gerechter-Amitai, Z. K., and Loegering, W. Q. 1977. Genes for low reaction to Puccinia graminis tritici in Aegilops and Triticum. Crop Sci. 17:830-832.

6. Gill, B. S., Sharma, H. C., Raupp, W. J., Browder, L. E., Hatchett, J. H., Harvey, T. L., Moseman, J. G., and Waines, J. G. 1985. Evaluation of Aegilops species for resistance to wheat powdery mildew, wheat leaf rust, Hessian fly and greenbug. Plant Dis. 69:314-316.

7. Hanson, W. D. 1958. Minimum family sizes for the planning of genetic experiments. Agron. J. 51:711-715.

8. Hsam, S. L. K., and Zeller, F. J. 2002. Breeding for powdery mildew resistance in common wheat (Triticum aestivum L.). Pages 219-238 in: The Powdery Mildews. A Comprehensive Treatise. R. R. Belanger, W. R. Bushnell, A. J. Dik, and T. L. W. Carver, eds. American Phytopathological Society, St. Paul, MN.

9. Johnson, J. W., Baenziger, P. S., Yamazaki, W. T., and Smith, R. T. 1979. Effects of powdery mildew on yield and quality of isogenic lines of 'Chancellor' wheat. Crop Sci. 19:349-352.

10. Kolmer, J. A. 1996. Genetics of resistance to wheat leaf rust. Ann. Rev. Phytopathol. 34:435-455.

11. Kolmer, J. A., 2005. Tracking wheat rust on a continental scale. Curr. Opin. Plant Biol. 8:441-449.

12. Long, D. L., and Kolmer, J. A. 1989. A North American system of nomenclature for Puccinia triticina. Phytopathology 79:525-529.

13. Long, D. L., Leonard, K. J., and Hughes, M. E. 2002. Virulence of Puccinia triticina in wheat in the United States in 1999. Plant Dis. 86: 15-19.

14. Manisterski, J., Segal, A., Levy, A. A., and Feldman, M. 1988. Evaluation of Israeli Aegilops and Agropyron species for resistance to wheat leaf rust. Plant Dis. 72:941-944.

15. Marais, G. F., McCallum, B., and Marais, A. S. 2006. Leaf rust and stripe rust resistance genes derived from Aegilops sharonensis. Euphytica 149:373-380.

16. Marais, G. F., Pretorius, Z. A., Marais, A. S., and Wellings, C. R. 2003. Transfer of rust resistance genes from Triticum species to common wheat. S. Afr. J. Plant Soil 20:193-198.

17. McVey, D. V., Long, D. L., and Roberts, J. J. 2002. Races of Puccinia graminis in the United States during 1997 and 1998. Plant Dis. 86:568572 .

18. Miller, T. E., Hutchinson, J., and Chapman, V. 1982. Investigation of a preferentially transmitted Aegilops sharonensis chromosome in wheat. Theor. Appl. Genet. 61:27-33.

19. Millet, E., Agami, M., Ezrati, S., Manisterski, J., and Anikster, Y. 2006. Distribution of Sharon goat grass (Aegilops sharonensis Eig) in Israel. Israel J. Plant Sci. 54:243-248.

20. Miranda, L. M., Murphy, J. P., Marshall, D., and Leath, S. 2006. Pm34: A new powdery mildew resistance gene transferred from Aegilops tauschii Coss. to common wheat (Triticum aestivum L.). Theor. Appl. Genet. 113:1497-1504.

21. Olivera, P. D., Anikster, Y., Kolmer, J. A., and Steffenson, B. J. 2007. Resistance of Sharon goat grass (Aegilops sharonensis) to fungal diseases of wheat. Plant Dis. 91:942-950.

22. Roelfs, A. P. 1985. Wheat and rye stem rust. Pages 4-37 in: The Cereal Rusts Vol. II: Diseases, Distribution, Epidemiology and Control. A. P. Roelfs and W. R. Bushnell, eds. Academic Press, Orlando, FL.

23. Roelfs, A. P., and Martens, J. W. 1988. An international system of nomenclature for Puccinia graminis f. sp. tritici. Phytopathology 78:526533.

24. Saari, E. E., and Prescott, J. M. 1985. World distribution in relation to economic losses. Pages 259-298 in: The Cereal Rusts. A. Roelfs and W. Bushnell, eds. Academic Press, Orlando, FL.

25. Sharma, H. C., and Gill, B. S. 1983. Current status of wide hybridization in wheat. Euphytica 32:17-31.

26. Snyman, J. E., Pretorius, Z. A., Kloppers, F. J., and Marais, G. F. 2004. Detection of adult-plant resistance to Puccinia triticina in a collection of wild Triticum species. Genet. Resour. Crop Evol. 51:591597. 
27. Valkoun, J., Hammer, K., Kucerova, D., and Bartos, P. 1985. Disease resistance in the genus Aegilops L. - stem rust, leaf rust, stripe rust, and powdery mildew. Kulturpflanze 33:133-153.

28. van Slageren, M. W. 1994. Wild wheats: A monograph of Aegilops L. and Amblyopyrum (Jaub. \& Spach) Eig (Poaceae). Agricultural University
Wageningen, the Netherlands; ICARDA, Aleppo, Syria.

29. Warham, E. J., Mujeeb-Kazi, A., and Rosas, V. 1986. Karnal bunt (Tillietia indica) resistance screening in Aegilops species and their practical utilization in Triticum aestivum improvement. Can. J. Plant Pathol. 8:65-70. 